\title{
MUCOLYTIC ENZYME SYSTEMS. VIII. INHIBITION OF HYALURO- NIDASE BY HUMAN BLOOD SERUM DURING THE NORMAL MENSTRUAL CYCLE AND PREGNANCY ${ }^{1}$
}

\author{
BY ERICK Y. HAKANSON 2 AND DAVID GLICK \\ (From the Department of Physiological Chemistry, the Medical School, \\ University of Minnesota, Minneapolis)
}

(Received for publication January 19, 1949)

While evidence has been presented in preceding publications of this series that the hyaluronidase inhibiting property of blood serum is increased in infectious diseases of both bacterial and viral origin $(1-4)$ and in cancer (5), changes that accompany certain normal physiological states have not been investigated.

It is well known that hyaluronidase plays an important role in fertilization by enabling the sperm to disperse the follicle cells surrounding the ovum (6-8), and that normal serum can inhibit this effect (9). Another aspect of particular interest in the light of the finding of Wattenberg and Glick (10) that certain of the steroid hormones inhibit the activity of hyaluronidase in vitro, would be alterations in the serum inhibitory level accompanying hormonal changes. Dorfman (11) has stated that men of reproductive age have a significantly lower range of hyaluronidase inhibitor levels than a comparable group of women.

Since hyaluronidase plays an important role in the invasion of the animal host by various toxic and infectious agents (12), the possibility that the serum inhibitor has a protective function should be kept in mind. Rosahn et al., (13) reported that pregnant rabbits were more resistant to vaccinia infection than the non-pregnant, and Aycock (14) claimed that castrated monkeys were less susceptible to poliomyelitis infection after the administration of estrogenic hormone. Sprunt, McDearman, and Raper (15-16) demonstrated that pseudopregnancy or the administration of estrogenic substances resulted in inhibition of the spreading of india ink in the rabbit skin.

From the foregoing it would appear that the serum inhibitor might have an effect on fertilization, and the female sex hormones might possibly

1 This work was supported by a grant from the Division of Research Grants and Fellowships, National Institute of Health, U. S. Public Health Service, Bethesda, Maryland.

${ }^{2}$ Junior Research Fellow, National Institute of Health. influence resistance to infection through their affect on the hyaluronidase inhibitor. In order to gain some information relative to these points, as well as to observe changes with respect to certain normal physiological states, the present investigation was concerned with the variations that occur in the level of the hyaluronidase inhibitor in the blood sera of women during the menstrual cycle and pregnancy.

\section{EXPERIMENTAL}

Materials and Methods. The details of the preparation of the materials, the viscosimetric assay method used, and the calculation of results followed the recently described modifications (10) of the original procedure and mode of expressing inhibition (1). The hyaluronidase was prepared from bovine testicle and the hyaluronic acid from human umbilical cord. Hyaluronidase inhibition was expressed as the per cent inhibition effected by $0.02 \mathrm{ml}$. of blood serum under the conditions employed. The per cent inhibition was defined as $\frac{100\left(R-R_{0}\right)}{R}$ where $\left(R_{0}\right)$ is the time required to reduce the viscosity of the reaction mixture to one-half its original value, and $(R)$ is the time required to reduce the initial viscosity to one-half after incubation of the $0.5 \mathrm{ml}$. of enzyme solution with $0.02 \mathrm{ml}$. of serum and $1.48 \mathrm{ml}$. of water for 10 minutes at $37.5^{\circ} \mathrm{C}$. Because the inhibitor loses activity rapidly on standing at room temperature, it is important that the collection of samples be as uniform as possible. The blood was collected in clean tubes, allowed to clot, centrifuged, and the serum removed and immediately frozen. To eliminate differences in various batches of enzyme and substrate, all serum samples were stored at $-20^{\circ} \mathrm{C}$. until the collections were complete for a given experiment. All of the samples were then assayed the same day using the same enzyme and substrate preparations.

\section{RESULTS}

For the menstrual study, 10 healthy, regularly menstruating, unmarried women ranging in age from 22-28 were chosen as subjects. Since other diseases can influence the inhibitor values, any subject who developed a "cold," "gastrointestinal" upset, or any other disability was dropped from the study. The results of experiments on eight 


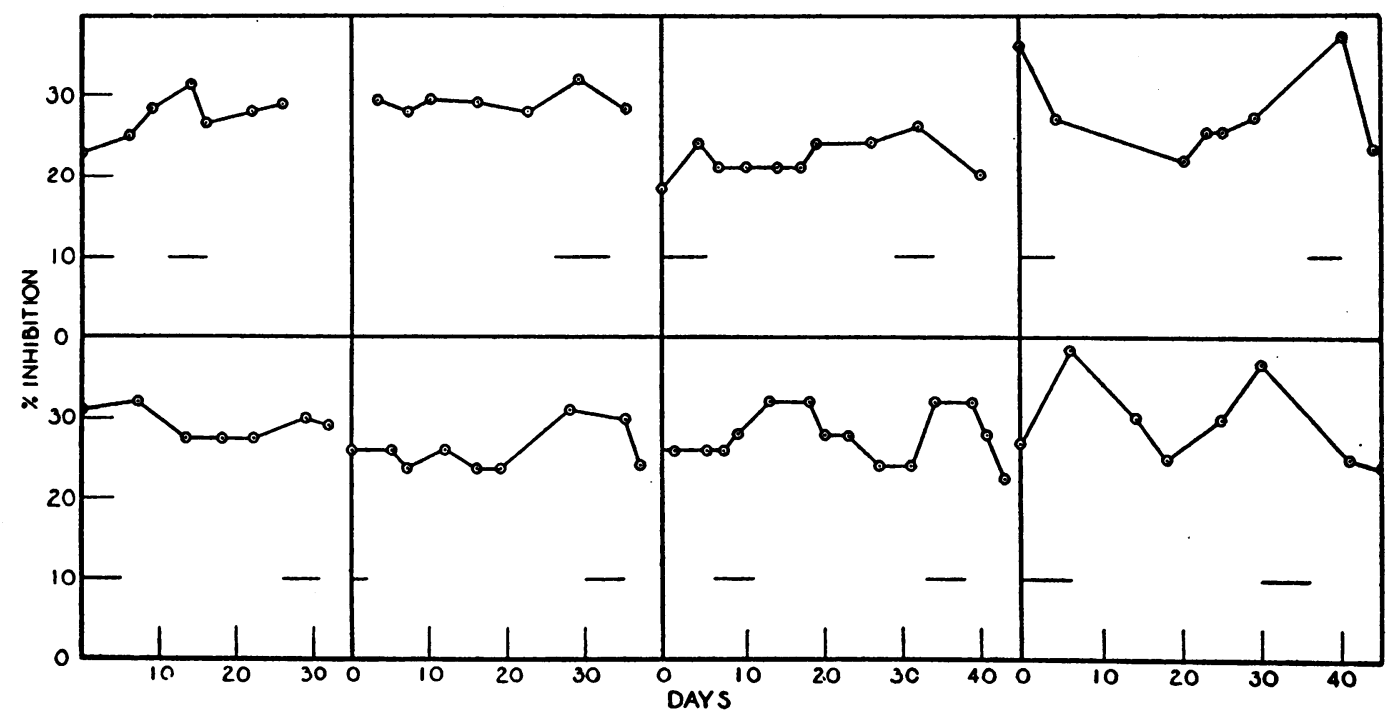

Fig. 1. Per Cent Inhibition of Hyaluronidase by Human Blood Serum During the Menstrual Cycle

Horizontal lines indicate menstrual periods.

individuals who completed the study are shown in Figure 1. The highest values are found during or immediately after actual menstruation although the magnitude of the changes was subject to great individual variation.

In the pregnancy study the blood samples were not collected from the same individual over the entire period of gestation. However, sera from groups of 10 women from each trimester of pregnancy were assayed and it was found that, although the inhibitor values increased somewhat during the latter period of gestation, the differ-

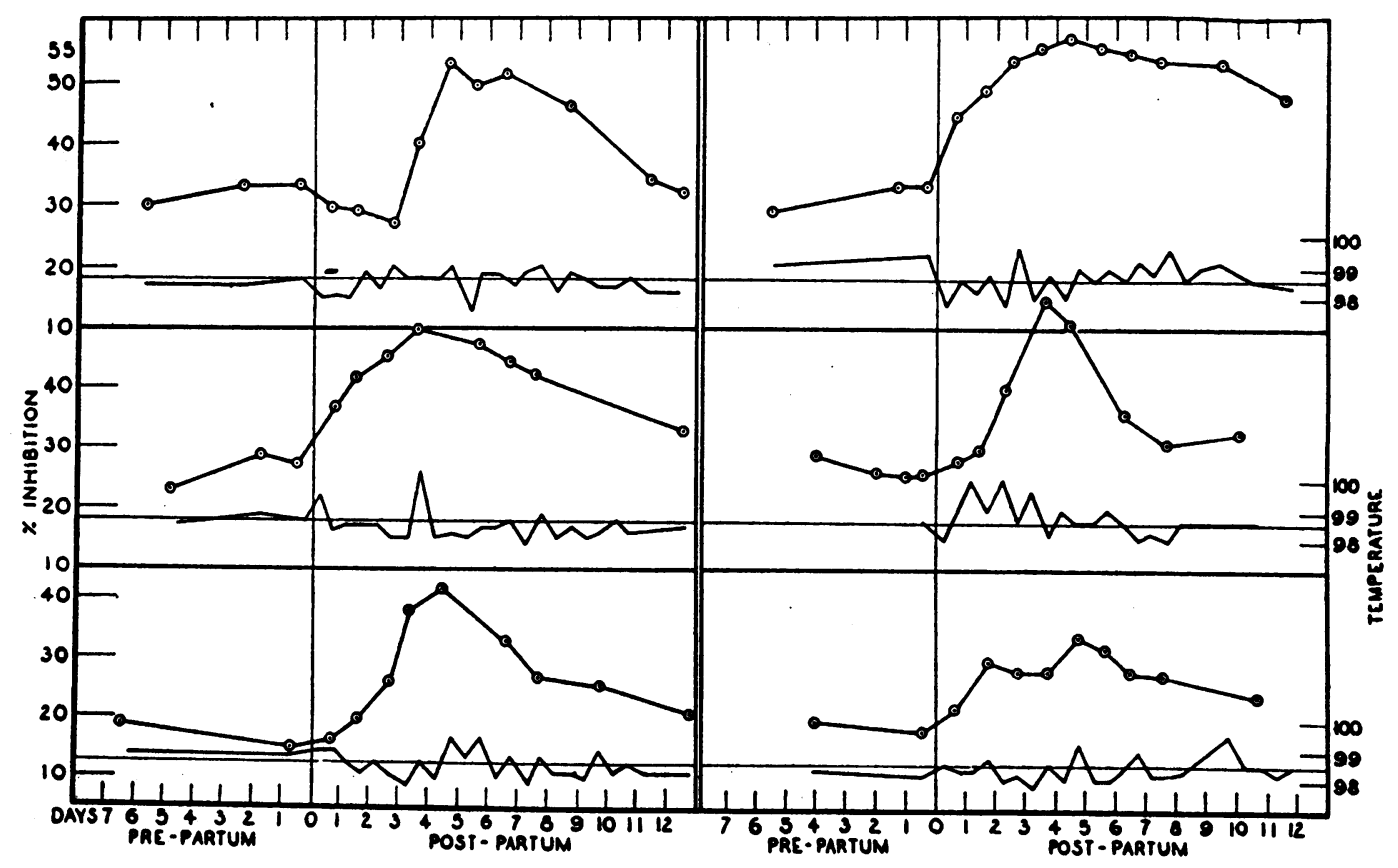

Fig. 2. Per Cent Inhibition of Hyaluronidase by Human Blood Serum During Pre- and Post-Partum Periods, and Accompanying Oral Temperatures 
ences were not statistically significant. Since the more dramatic changes in the inhibitor level were found to take place just before and during delivery, studies on 16 uncomplicated pregnancies were carried out beginning about a week before the expected date of confinement and continuing for about 10 days post-partum. The data of six representative cases are shown in Figure 2. It is clear from the curves that there is a consistent and significant rise in the per cent inhibition, which reaches a peak in from two to five days post-partum and is almost back to the pre-partum level by the 10th day. The rise can be detected in some cases as early as two hours after delivery. The temperature curves, which contain the highest recorded temperature for each 12-hour period, show that this elevation is not consistently paralleled by a rise in body temperature.

\section{DISCUSSION}

Although no abrupt change in the level of the hyaluronidase inhibitor was observed during, or soon after, the expected times of ovulation, in some of the cases the lowest values did occur during the middle of the cycle. However, the significance of this change is in doubt since its magnitude was negligible in some of the women. Further doubt of a correlation between inhibitor levels and sex hormonal changes follows from a consideration of the fact that no appreciable inhibitor changes were observed during the course of pregnancy. The point deserving major emphasis is the unequivocal post-partum rise in the level of the serum inhibitor. The significance of this observation is not clear at present. There may be a common factor, such as tissue destruction, in the variations of inhibitor noted in this investigation and the increase reported for infection and cancer. This possibility is being pursued further.

\section{SUMMARY}

Studies were carried out on the inhibitory effect of blood sera from 10 normal women during various phases of the menstrual cycle, and from 16 women with uncomplicated pregnancies before, during, and after delivery.

It was found that the highest inhibitor levels tended to occur during menstruation, although the individual variation in this elevation was great. The data do not permit of a correlation with sex hormonal changes.
No significant change was found during pregnancy or labor. A marked post-partum rise was observed which reached its maximum from the second to fifth days after delivery.

\section{BIBLIOGRAPHY}

1. Glick, D., and Gollan, F., Mucolytic enzyme systems. I. Inhibition of hyaluronidase by serum in poliomyelitis. J. Inf. Dis., 1948, 83, 200.

2. Grais, M., and Glick, D., Mucolytic enzyme systems. II. Inhibition of hyaluronidase by serum in skin diseases. J. Invest. Derm., 1948, 11, 259.

3. Glick, D., and Campbell, B., Mucolytic enzyme systems. V. Anaphylactic effects on hyaluronidase inhibitor in serum of normal and herpetic rabbits. Proc. Soc. Exper. \& Biol. Med., 1949, 70, 29.

4. Grais, M. L., and Glick, D., Mucolytic enzyme systems. VI. Inhibition of hyaluronidase by serum in infectious diseases. J. Inf. Dis., in press.

5. Hakanson, E. Y., and Glick, D., Mucolytic enzyme systems. III. Inhibition of hyaluronidase by serum in human cancer. J. Nat. Cancer Inst., 1948, 9, 129.

6. Fekete, E., and Duran-Reynals, F., Hyaluronidase in the fertilization of mammalian ova. Proc. Soc. Exper. Biol. \& Med., 1943, 52, 119.

7. Rowlands, I. W., Capacity of hyaluronidase to increase the fertilizing power of sperm. Nature, 1944, 154, 332.

8. Swyer, G. I. M., Role of hyaluronidase in fertilisation. Lancet, 1946, 2, 755.

9. Leonard, S. L., and Kurzrok, R., A study of hyaluronidase-effects on the follicle cells of ovulated rat ova. Endocrinology, 1945, 37, 171.

10. Wattenberg, L. W., and Glick, D., Mucolytic enzyme systems. VII. Effects of tissue extracts and body fluids, certain sterids, and hemoglobin derivatives on hyaluronidase activity. J. Biol. Chem., in press.

11. Dorfman, A., Ott, M. L., and Whitney, R., The hyaluronidase inhibitor of human blood. J. Biol. Chem., 1948, 174, 621.

12. Duran-Reynals, F., Tissue permeability and spreading factors in infection. A contribution to the hostparasite problem. Bact. Rev., 1942, 6, 197.

13. Rosahn, P. D., Hu, C. K., and Pearce, L., The reaction of normal and rabbit-pox immune adult rabbits to vaccination with vaccine virus. J. Immunol., 1936, 31, 59.

14. Aycock, W. L., Alterations in autarceologic susceptibility to experimental poliomyelitis. Proc. Soc. Exper. Biol. \& Med., 1936, 34, 573.

15. Sprunt, D. H., McDearman, S., and Raper, J., Studies on the relation of the sex hormones to infection. 1. The effect of the estrogenic and gonadotropic hormones on vaccinia and the spreading factor. J. Exper. Med., 1938, 67, 159.

16. Sprunt, D. H., and McDearman, S., Studies on relationship of sex hormones to infection; effect of pseudopregnancy on the spread of india ink in the skin of rabbits. Endocrinology, 1939, 25, 308. 